\title{
What Ottoman Nationality Was and Was Not
}

\author{
Will Hanley
}

\begin{abstract}
The Ottoman Nationality Law of 1869 is considered a milestone in the development of late Ottoman citizenship and national belonging. The content of the legislation itself, and the history of its implementation by the Legal Bureau of the Ottoman Foreign Ministry, reveal that the law was developed to define membership in marginal and difficult cases of shared allegiance. Its focus was acquisition and loss of membership rather than the rights of citizenship. Ottoman nationality law was largely consistent with international norms, with two particularities: special attention to marriages between Ottoman and Persian subjects and special impediments to the naturalization of Ottomans abroad. In making the case that Ottoman nationality was a historical factor distinct from nationalism or citizenship, the article offers a detailed treatment of a 1909 draft revision of the 1869 law.
\end{abstract}

Nationality legislation was a nineteenth-century invention, and the Ottomans were early adopters. The Ottoman nationality law (tâbiiyet-i osmaniye kanunnamesi) of 1869 appeared at a time before any commonly-agreed international understanding of the basic elements of such legislation - this consensus emerged only after the First World War. In the third quarter of the nineteenth century, only a minority of states had enacted specific legislation to govern nationality. Many more defined state membership as part of a fundamental law, such as a constitution (United States), a civil code (France, Greece) or even a compendium (Egypt). ${ }^{1}$ In these cases, membership boundaries developed directly out of legal definitions of the civil and political rights of members. In independent nationality regulations such as the 1869 Ottoman law, on the other hand, acquisition and loss of nationality (rather than the rights and obligations that nationality conveyed) was the primary concern.

1. Major collections of nationality laws include George Cogordan, Droit des gens: la nationalité au point de vue des rapports internationaux, 2nd ed. (Paris: L. Larose et Forcel, 1890); Richard W. Flournoy and Manley O. Hudson, eds., A Collection of Nationality Laws of Various Countries, as Contained in Constitutions, Statutes and Treaties (New York: Oxford University Press, 1929); United Nations, Laws Concerning Nationality, United Nations Legislative Series 4 (New York: United Nations, 1954).

Journal of the Ottoman and Turkish Studies Association, Vol. 3, No. 2, pp. 277-298 Copyright (C) 2016 Ottoman and Turkish Studies Association. doi:10.2979/jottturstuass.3.2.05 
As membership became more narrowly and thoroughly defined, ambiguities unresolved in comprehensive codes and constitutions required the sort of focused directives that nationality laws contain. Thus independent nationality laws, as in the Ottoman case, represent an evolution in procedure based on practical experience.

In many of its aspects, the Ottoman nationality law resembled nationality laws of other states issued before 1869 and after. All such laws seek to regulate the core scenarios for the acquisition of nationality-birth, descent, naturalization through residence or marriage - with minor variance in the particulars of implementation. Yet the Ottoman nationality law has been identified as the origin point of a very different set of practices: those of modern political identity and citizenship. Semantically, the term tâbiiyet supports various shades of meaning: nationality, subjecthood, affiliation, allegiance, "under the sovereignty of." It does not support translation as "citizenship," however; those inscribing the 1869 law into a genealogy of citizenship must therefore be referring to the function of the law. But when one examines the content of the legislation, it is clear that the law is not concerned with functions typically associated with citizenship. Citizenship is practiced by those whose full membership is most secure, while nationality is the concern of those whose membership is least certain. The Ottoman nationality law concerns these latter individuals: children and wives of foreigners, orphans, emigrants, and immigrants.

I am not arguing that there was no Ottoman citizenship during the closing decades of the empire. Certainly there was. But the 1869 law describes forms of affiliation that do not constitute citizenship according to any useful understanding. The law was one step in the gradual imagination and constitution of a secular, state-centered membership regime. Was it the end of an 1839-69 trajectory of civil emancipation, or the beginning of a trajectory of political participation recurring in 1876 and 1908? Or is Ottoman nationality situated along another timeline, or a cul-de-sac of its own?

This article approaches these questions in five sections. The first maps out the major patterns of scholarly reference to the 1869 law. The second examines the content of the law itself and the circumstances of its promulgation. The third section traces the evolution and interpretation of law from 1869 to the second constitutional period, with particular emphasis on a detailed $1909 \mathrm{draft}$ revision of the law that has not previously been analyzed. The fourth section takes up the broad question of acquisition of Ottoman nationality. The fifth section treats two issues particular to Ottoman nationality: marriage to Persian subjects and naturalization of Ottomans abroad. In sum, the article argues that

2. Thanks to one of my anonymous reviewers for this last suggested translation. 
Ottoman nationality functioned not as a headwater of late imperial or national identity, but as a dike or bank shored up by the 1869 law that sought to hold a fluid population within the Ottoman watershed.

\section{Citizenship, Ethnicity, Sect, or Nationality?}

Scholars exploring the last half-century of Ottoman history frequently invoke the 1869 Ottoman nationality law. They define its character using a variety of labels of belonging, notably ethnicity, sect, and citizenship. These categories are ascribed to the law, but their pertinence is rarely explained. As a result, the particulars of the law itself remain indistinct and its functions uncertain. A remedy for murkiness in scholarly treatment of the Ottoman nationality law is to consider with greater precision what the law meant, and for whom: it is no surprise that different people made different things of it. The late Ottoman state was a functionally differentiated entity, and so there are several answers to this question, each valid but also discreet from others. Moreover, nationality was a novel legal concept in the last decades of the nineteenth century, not only in the Ottoman Empire but also worldwide. Nevertheless, the 1869 nationality law had positive content and well-defined limits which must be observed if its meaning is to be understood.

One line of scholarship situates the 1869 law in the course of the long rise of sectarianism and ethnic nationalism in the Ottoman Empire. In his study of nationalist divisions in the late Ottoman Empire, Feroz Ahmad treats nationality as a form of sectarian or ethnic identity (akin to the use of nationality in the Russian imperial context), while translating the term tâbiiyet in the 1869 law as "citizenship." Ahmad suggests that the 1869 law was meant to encode a "patriotic identity" in the Ottoman population, which the reformers hoped would "transform subjects into citizens."3 Kemal Karpat's widely-cited 1982 essay on millets and nationality suggests that nationality "in the sense of ethnicnational identity, drew its essence from the religious-communal experience in the millet, while citizenship — a secular concept—was determined by territory."4 This distinction between nationality and citizenship proves difficult to unpack: the 1869 law made no reference to religion or ethnicity. Citizenship and territory, meanwhile, are not congruous concepts in the Ottoman Empire: unlike the United States of America, Ottoman law attributed nationality by territory of birth only rarely - in fact, a good part of the nationality law was

3. Feroz Ahmad, The Young Turks and the Ottoman Nationalities: Armenians, Greeks, Albanians, Jews, and Arabs, 1908-1918 (Salt Lake City: University of Utah Press, 2014), 3-4.

4. Kemal H. Karpat, "Millets and Nationality: The Roots of the Incongruity of Nation and State in the Post-Ottoman Era," in Christians and Jews in the Ottoman Empire, ed. Benjamin Braude and Bernard Lewis (New York: Holmes \& Meier Publishers, 1982), 141. 
devoted to specifying the conditions of jus soli acquisition. In Karpat's view, nationality was rooted in religion and language, while tâbiiyet was a term that reconciled millet status and European citizenship. ${ }^{5}$ He argues that by 1850 , non-Muslim Ottoman subjects (millet members) were already treated as Ottoman citizens, and that the 1869 law was a "mere technicality that legalized and clarified further an already established concept."6

This is a moment to consider what it meant to be "treated as an Ottoman citizen." Ottoman membership was a meaningful and difficult question for many branches of the empire's administration. The Interior Ministry, the Office of the Şeyhülislam, the Chamber of Deputies (meclis vükela), the Population Bureau (sicill-i nüfus), and the Council of State itself all engaged with questions of nationality. As the other articles in this issue show, the law bore various shades of meaning for all of these authorities. They exercised control over citizens through conscription, taxation, censorship, mobility controls, education, registration, and prosecution. Nationality was never essential to any of these administrative practices; however, its core functions belonged to the foreign ministry. The 1869 text, legal in nature and focused on external questions, was written using the language of international law in order to address other states. It was only secondarily a piece of domestic legislation. Acknowledging this fact can help to explain the various and contradictory roles that law has been assigned in the scholarly literature.

Like Karpat, Bruce Masters locates nationality in the field of sectarianism, but he does so without confusing it with citizenship (which he assigns to the 1876 constitution). ${ }^{7}$ He describes the "reconfiguring of religious identity as nationality," as against the development of a unifying Ottoman nationalism, during the closing decades of the nineteenth century. ${ }^{8}$ For Ussama Makdisi and Selim Deringil, the 1869 law represented a decoupling of religion and citizenship. ${ }^{9}$ Because Ottoman subjecthood remained tightly associated with Muslims, however, the law created myriad problems, not least in cases of Muslims (including new converts) who were nationals of other states, as Michael Christopher Low shows in this issue. ${ }^{10}$

5. Ibid., 165 .

6. Ibid., 162.

7. Bruce Alan Masters, Christians and Jews in the Ottoman Arab World: The Roots of Sectarianism (Cambridge, UK: Cambridge University Press, 2001), 140.

8. Ibid., 196. Note, however, that he does not cite the 1869 law in this study.

9. Ussama Makdisi, “Ottoman Orientalism," American Historical Review 107, no. 3 (2002): 778; Selim Deringil, Conversion and Apostasy in the Late Ottoman Empire (Cambridge, UK: Cambridge University Press, 2012), 157.

10. Deringil, Conversion and Apostasy, 181-86. 
A second approach to the nationality law is pursued by scholars interested in political citizenship. ${ }^{11}$ This approach seizes on the 1869 law as the referent for the Ottoman subjects of article six of the 1876 constitution: "All subjects of the Empire are called Ottoman (Devlet-i Osmaniye tâbiiyetinde bulunan fertlerin)...the status of an Ottoman is acquired and lost according to conditions specified by law (Osmanlı sıfatı kanunen muayyen olan ahvale göre istihsal ve izaa olunur)." 12 These scholars emphasize the ways in which residents of the empire came to articulate their aspiration to political participation, whether through representation (for example, in the 1876 parliament, secret societies, or the governments of the second constitutional period) or through discourse, notably in the press. For these scholars, the importance of the nationality law is its formal designation of membership in the class of Ottomans. Scholars who have examined the "imperial citizenship" of Ottomans have been alert to the question of legal membership in the empire. ${ }^{13}$ Too often, though, this citizenship seeks a referent that simply does not exist. Karpat's rich study of late Ottoman membership attributes a political character to the "Citizenship Laws of 1864 [sic]" that it simply did not possess: "Ottomanism implied that the country belonged, or should belong, to its citizens and that their ownership of the state was based on their citizenship status as 'Osmanli' or Ottomans, regardless of religious affiliation." 14 The few Ottomans who might have conceived of themselves as citizens owning the country did not do so because of the nationality law of 1869 , which only admitted the state's ownership of its subjects.

Lawyers have engaged with the 1869 law using a third approach. Some see it as the fundament of Ottoman private law-it is, for example, the first law printed in Aristachi Bey's massive six-volume collection of Ottoman legislation. More recently, Cihan Osmanağaoğlu's book offers a detailed

11. Ariel Salzmann, "Citizens in Search of a State: The Limits of Political Participation in the Late Ottoman Empire," in Extending Citizenship, Reconfiguring States, ed. Michael P. Hanagan and Charles Tilly (Lanham, MD: Rowman \& Littlefield Publishers, 1999), 37-66; Engin Fahri Isin, "Citizenship after Orientalism: Ottoman Citizenship," in Citizenship in a Global World: European Questions and Turkish Experiences, ed. Fuat Keyman and Ahmet Icduygu (London: Routledge, 2005), 31-51.

12. This attribution comes in İsmaịl Aydingün and Esra Dardağan, "Rethinking the Jewish Communal Apartment in the Ottoman Communal Building," Middle Eastern Studies 42, no. 2 (2006): 325.

13. For example, Michelle Campos, Ottoman Brothers: Muslims, Christians, and Jews in Early 20th Century Palestine (Stanford: Stanford University Press, 2010); Julia Phillips Cohen, Becoming Ottomans: Sephardi Jews and Imperial Citizenship in the Modern Era (New York: Oxford University Press, 2014).

14. Kemal H. Karpat, The Politicization of Islam: Reconstructing Identity, State, Faith, and Community in the Late Ottoman State (Oxford: Oxford University Press, 2001), 315. 
legal reading of the law. ${ }^{15}$ Lawyers interested in nationality in Ottoman successor states have looked back on the 1869 law in order to understand subsequent statutes in Turkey and elsewhere. Gianluca Parolin's study of citizenship in the Arab world gives a brief but serious treatment of the 1869 law itself, in the context of his broader argument about kin, religious, and national belonging. ${ }^{16}$ Constantin Iordachi's work on Balkan nationality and Mutaz Qafisheh's work on Palestinian nationality also elaborate continuities with the 1869 law. ${ }^{17}$ Accounts of citizenship in the Republic frequently take 1869 as their point of departure. ${ }^{18}$ These legal accounts are concerned with continuities with the present day, rather than understanding Ottoman nationality on its own terms. Nevertheless, their specialized domain clarifies the law's own vocabulary.

Historians who are interested in the law as a means of accessing social history pursue a fourth path. Karen Kern (on marriage), James Meyer (on migration), Abdul-Karim Rafeq and Sibel Zandi-Sayek (on property), and Julia Phillips Cohen and Sarah Abrevaya Stein (on Jews) each find uses for the 1869 law. ${ }^{19}$ Again, however, the mechanisms by which political citizenship relates to acquisition and loss of legal membership (the main subjects of the

15. Cihan Osmanağaoğlu, Tanzimat Dönemi İtibarlyla Osmanlı Tâbiiyyetinin (Vatandaşlı̆̆ının) Gelişimi (Istanbul: Legal, 2004).

16. Gianluca Paolo Parolin, Citizenship in the Arab World: Kin, Religion and Nation-State (Amsterdam: Amsterdam University Press, 2009), 73-74 and passim.

17. Constantin Iordachi, "The Ottoman Empire: Syncretic Nationalism and Citizenship in the Balkans," in What Is a Nation?: Europe 1789-1914, ed. Timothy Baycroft and Mark Hewitson (Oxford: Oxford University Press, 2006), 130-31; Mutaz M. Qafisheh, The International Law Foundations of Palestinian Nationality : a Legal Examination of Nationality in Palestine Under Britain's Rule (Leiden: Martinus Nijhoff, 2009).

18. For instance, Zeynep Kadirbeyoglu, "Changing Conceptions of Citizenship in Turkey," in Citizenship Policies in the New Europe, ed. Rainer Bauböck, Bernhard Perchinig, and Wiebke Sievers (Amsterdam: Amsterdam University Press, 2007), 419-38.

19. Karen M. Kern, Imperial Citizen: Marriage and Citizenship in the Ottoman Frontier Provinces of Iraq (Syracuse: Syracuse University Press, 2011); James H. Meyer, "Immigration, Return, and the Politics of Citizenship: Russian Muslims in the Ottoman Empire, 1860-1914," International Journal of Middle East Studies 39, no. 1 (2007): 15-32; Abdul-Karim Rafeq, "Ownership of Real Property by Foreigners in Syria, 1869 to 1873," in New Perspectives on Property and Land in the Middle East, ed. Roger Owen (Cambridge, MA: Harvard University Press, 2001), 175-240; Sibel Zandi-Sayek, Ottoman Izmir: The Rise of a Cosmopolitan Port, 1840-1880 (Minneapolis: University of Minnesota Press, 2012); Cohen, Becoming Ottomans; Sarah Abrevaya Stein, "Protected Persons? The Baghdadi Jewish Diaspora, the British State, and the Persistence of Empire," American Historical Review 116, no. 1 (2011): 80-108; idem, "Citizens of a Fictional Nation: Ottoman-Born Jews in France during the First World War," Past \& Present 226, no. 1 (2015): 227-54. 
1869 law) are not important concerns in the literature on citizenship. ${ }^{20}$ So, for instance, we do not discover the administrative location of citizenship, or understand why nationality was the purview of Ottoman Foreign Ministry, rather than of mayors (as was the case in Greece and Hungary) or the Interior Ministry. ${ }^{21}$ The literature has not managed to disaggregate political questions from questions of unitary subjecthood. Hence Iordachi's assertion:

\footnotetext{
Until the advent of the First World War, the Ottoman state organization was thus dominated by the contradiction between the emergence of a generic Ottoman citizenship based on the legal equality of all its inhabitants, irrespective of their religion or ethnicity, and calls for an Islamic based Ottoman nationality, supported by a legal order that would favour the political and socio-economic interests of the Muslims. ${ }^{22}$
}

He seems to confuse domestic and foreign ministry questions, and political and property rights. Tanzimat legal equality was a different question altogether, figuring not at all in the nationality laws, though the questions are certainly mingled in the secondary literature, which often (and imprecisely) substitutes "citizenship" for tâbiiyet. Scholars seeking to use nationality as an avenue to address other historical topics have been poorly served by a literature that does not specify what Ottoman nationality was and was not.

\section{The Ottoman Nationality Law of 1869}

The four lines of interpretation described above put a lot of weight on narrow shoulders: the 1869 nationality law contains just nine articles..$^{23}$ The first three articles deal briskly with the three main means of nationality acquisition: descent (children of Ottoman fathers are Ottomans), birth (foreigners born in the Ottoman domains may acquire Ottoman nationality at the age of majority), and residence (foreigners may acquire Ottoman nationality after five years of residence). The middle articles concern the empire's sovereignty over its nationality, offering the executive a full range of possible powers over the

20. Consider the careful explanation of 1869's acquisition rules in Campos, Ottoman Brothers, 61.

21. Intriguingly, in his archivally vivid 2012 study of Ottoman belonging, Selim Deringil frequently thanks Sinan Kuneralp for reference to sources, but he does not cite any document from the Foreign Ministry Legal Bureau, about which Kuneralp published an extensive document collection in the same year. Is this an indication of the isolation of the bureau from the administrative mainstream?

22. Iordachi, "Syncretic Nationalism," 133.

23. The law was published in Düstür 1 (1289/1872): 16-18. A French translation appears in Gregorius Aristarchi Bey, Législation ottomane, ou Recueil des lois, réglements, ordonnances, traités, capitulations et autres documents officiels de l'Empire ottoman, 6 vols. (Constantinople: Freres Nicolaïdes, 1873), 1:7-8. 
nationality status of individual subjects: the Imperial Council may make exceptions to the requirements just listed, it may refuse permission for Ottomans to quit Ottoman nationality, and (conversely) it can strip those who acquire foreign nationality of their Ottoman nationality and bar them from Ottoman territory. The seventh and eight articles concern the nationality of wives and children who do not share the nationality of their husbands or fathers. The ninth article states that anyone inhabiting the empire is considered an Ottoman by default, unless they can demonstrate otherwise.

Although it resembles European nationality legislation, the 1869 law was also marked by influences particular to the empire. Foremost among these was the Capitulations, a set of long-standing extraterritorial privileges and exemptions for foreign subjects in the Ottoman domains. ${ }^{24} \mathrm{By}$ the middle of the nineteenth century, the professionalizing Tanzimat bureaucracy was combatting all and any limitations on Ottoman sovereignty. A modern state required a well-defined territory and a well-defined population. Clarifying and standardizing membership was no simple undertaking for a complex empire characterized by decentralized authority and differentiated status and jurisdiction.

After the Islahat Ferman of 1856, which leveled civil distinctions between Muslim and non-Muslim Ottoman subjects, the reformers could tackle the next great membership problem: protégés (beratllar) of foreign states. Protégés, Ottoman subjects who enjoyed the exemptions and privileges of foreigners, possessed a hybrid status that became intolerable for the reformers. In 1863, the Ottoman administration issued a regulation that dramatically restricted the possibility of protection. ${ }^{25}$ Because Ottoman subjects now possessed equal rights, the legislation asserted, there was no more need for foreign protection. Foreign embassies and consulates and Christian and Jewish religious institutions could continue to protect a limited number of employees, but all other protégés now faced a choice: they had to naturalize as foreign subjects, or submit to the territorial jurisdiction that went along with their Ottoman subjecthood and residence.

The 1863 protégé regulation did not clarify everyone's status overnight. Individuals discovered the practical implications of the legal change only gradually, as occasions to investigate and clarify their status arose. But the Ottoman bureaucracy now had the legal basis to clarify and simplify the state's

24. For background on the capitulations, see Maurits H. van den Boogert, The Capitulations and the Ottoman Legal System: Qadis, Consuls, and Beratlis in the 18th Century (Leiden: Brill, 2005); Umut Özsu, "Ottoman Empire," in The Oxford Handbook of the History of International Law, ed. Bardo Fassbender and Anne Peters (Oxford: Oxford University Press, 2013), 429-48.

25. Règlement relatif aux consulats étrangers d'août 1863, and an 1865 addendum, reproduced in Pierre Arminjon, Étrangers et protégés dans l'Empire ottoman (Paris: A. ChevalierMaresq \& cie, 1903), 325-30. 
relationship with the greatest part of its population. Having made this stride, it discovered the next stumbling block in defining a well-bounded population subject to its sovereignty. Quite naturally, many protégés (especially those possessing wealth or power) reacted to the 1863 regulation by naturalizing with a foreign state, but these newly-minted foreign nationals also remained Ottoman residents and (in most cases) Ottoman subjects. Thus the 1863 regulation, intended to clarify whether an individual was an Ottoman or a foreigner, led many to establish status as Ottomans and foreigners. It was this problem that the 1869 Ottoman nationality law aimed to solve.

As we have seen, scholarship citing the Ottoman nationality law of 1869 has quite consistently traced its lineage to the Tanzimat edicts of 1839 and $1856 .{ }^{26} \mathrm{An}$ interest in Ottoman citizenship - unquestionably a key concern of the Tanzimat edicts - can quite innocently lead to this reading of the 1869 law (which entails the need to explain away a problem of terminology, because the text refers to tebaa, which means subjects, not citizens). This "citizenship" misreading misses the immediate context of the law: its most direct connection was to the protégé regulation of 1863 . Ali Pasha, the grand vizier who promulgated the law, made this connection plain in an April 1869 memorandum circulated to foreign powers through the Ottoman ambassadors abroad. ${ }^{27} \mathrm{He}$ stated that the Ottoman government supports the individual freedom to choose nationality, but that the capitulations had perverted that freedom in the Ottoman domains. The privileges of foreigners naturally led Ottomans to seek foreign protection, and protégés came to outnumber foreigners themselves. "The imperial government believed that it had partially remedied this situation with the 1863 regulation...but our hope was not realized": the number of protégés dropped, but the number of naturalized foreigners rose apace. The administration tried to be patient, Ali's memorandum continues, believing that no foreign state would encourage Ottomans to naturalize in order to further its own interests in the empire. Furthermore, he points to Ottoman expectations invested in a different 1856 document: the Treaty of Paris, which promised a revision of the capitulations. When these hopes were "cruelly denied," the Ottoman government had no choice but to pass its nationality law of 19 January 1869 .

Specification of nationality law was a trend. French Civil Code provisions were refined many times, notably with a comprehensive law in $1883 .{ }^{28}$ Russia's mid-nineteenth-century collection of laws (svod zakonov) governed personal status generally, but the question of naturalization required far more

26. Karpat, "Millets and Nationality," 163; Salzmann, "Citizens in Search of a State," 39-45; Campos, Ottoman Brothers, 61; Kern, Imperial Citizen, 14-16.

27. This memorandum is reproduced in Cogordan, Droit des gens, 547-51.

28. For a comprehensive study, see Patrick Weil, How to Be French: Nationality in the Making since 1789 (Durham: Duke University Press, 2008). 
detailed specification, which came in a separate edict in $1864 .{ }^{29}$ States without fundamental compilations of laws, like the Ottoman Empire, introduced independent nationality legislation. German nationality, for instance, depended on the stand-alone law of 1 June $1870 .{ }^{30}$ Britain produced a Naturalization Act in the same year, developing its Nationality Acts of 1730 and 1844. The Ottoman law of 1869 was less detailed than these acts, but roughly contemporary to them. Kuneralp has showed that a French and a British lawyer advised the Ottoman Foreign Ministry during the 1860s; these men would have considered these European laws when consulted on the Ottoman nationality law. ${ }^{31}$

In addition to these general influences, Ottoman nationality law was shaped by the policies of the empire's neighbors, who "competed" for its subjects. Kern's work details the Ottoman-Iranian contest over nationality at the frontier. ${ }^{32}$ Iordachi suggests that "the Ottoman citizenship law can be characterized...as reactive to nationality laws passed by neighbouring Christian states, a feature highlighted by the delegation of citizenship matters to the Ministry of Foreign Affairs." 33 He argues that the "inclusive" nationality rules of Greece and other Balkans states antedated the 1869 law and, as its direct competitors, shaped its provisions. Greek nationality was governed by its Civil Code of $1856 .{ }^{34}$ Bulgaria introduced comprehensive nationality laws in 1883 (revising the constitution of 1879) and in 1903. ${ }^{35}$ Before its final division from the Ottoman Empire in 1878, Romania's Civil Code of 1864 and Constitution of 1866 based membership on religion; in 1878 these restrictions were lifted, and an 1880 rule allowed the naturalization of any Ottoman residents, except those visiting temporarily to work lands they owned. ${ }^{36}$

The most important and controversial provisions of the 1869 law were the controls over expatriation contained in articles six and seven. By refusing to acknowledge any nationality change by an Ottoman subject without permission, the empire aimed to reassert its sovereignty over its own subjects on its own territory, badly eroded as a result of the capitulations. While early twentieth-

29. Cogordan, Droit des gens, 519-24.

30. British and Foreign State Papers 79 (1887-88), 147-51. A stimulating comparison of German and French nationality is Rogers Brubaker, Citizenship and Nationhood in France and Germany (Cambridge, MA: Harvard University Press, 1992).

31. Sinan Kuneralp and Emre Öktem, eds., Chambre des conseillers légistes de la Sublime Porte: rapports, avis et consultations sur la condition juridique des ressortissants étrangers, le statut des communautés non musulmanes et les relations internationales de l'Empire ottoman (1864-1912) (Istanbul: Isis Press, 2012), 10.

32. Kern, Imperial Citizen.

33. Iordachi, "Syncretic Nationalism," 131.

34. Cogordan, Droit des gens, 486.

35. Flournoy and Hudson, Collection of Nationality Laws, 161-69.

36. Estanislao Severo Zeballos and André Bosq, La nationalité au point de vue de la législation comparée et du droit privé humain (Paris: L. Tenin, 1914), 1:297-98. 
century commentators hinted that this measure constrained individual freedom, they also had to acknowledge that many other states had provisions similar to the Ottomans. ${ }^{37}$ In any event, the Ottomans were not claiming anything so pervasive as Russia's perpetual allegiance. ${ }^{38}$ Thus the great powers (if grudgingly at times) agreed that, in the words of a French Foreign Ministry committee that studied the 1869 law, it contained "nothing contrary to international law in general, and it does not infringe on the rights and privileges granted under the capitulations and established by custom." ${ }^{39}$

\section{Evolution and Interpretation of the Nationality Law}

It is not surprising that the 1869 law, meant to curb widespread jurisdiction dodging through expatriation, met considerable opposition. This controversy was mentioned in an izahname (explication) sent to provincial governors in March 1869 and in Ali Pasha's April memorandum to foreign consuls. These two documents were among a number of clarifications and supplemental laws that the Ottoman government issued in the years after 1869 in order to elaborate the law's provisions. The izahname, dated 4 Zilhicce 1285 (26 March 1869 ) and addressed to provincial governors and distributed as well to foreign consulates in the empire, shows that questions requiring clarification arose just weeks after the law was promulgated. ${ }^{40}$ The text emphasized that the law's force was not retroactive, which supports my contention that its function was to complement and extend existing instruments defining and refining the Tanzimat membership regime. The document also states that nationality change under the new law cannot be used to dodge any existing criminal or civil case; cases antedating the law will be pursued in their original venue. Certain lacunas of the law are addressed: the age of majority is to be defined by the norms of each community. The izahname cautions provincial authorities that only the central authorities can dispense the permission to expatriate (under article five) and order the banishment or expulsion of those who expatriate without permission (article six). Again, this suggests that the purpose of the nationality law was to settle otherwise intractable puzzles, rather than to manage everyday administration on the ground.

Ali Pasha's April 1869 memorandum responds at some length to the claim that the Sublime Porte lacked the legal authority to legislate Ottoman nationality

37. Emmanuel R. Salem, "De la nationalité en Turquie," Journal du droit international privé (Clunet) 32 (1905): 585-91, 872-83; 33 (1906): 1032-41; 34 (1907): 51-56.

38. On Russian nationality, see Eric Lohr, Russian Citizenship: From Empire to Soviet Union (Cambridge, MA: Harvard University Press, 2012).

39. "Avis du comité de contentieux auprès du ministère des affaires étrangères," reprinted in Cogordan, Droit des gens, 554.

40. A French translation appears in Aristarchi Bey, Législation ottomane, 1:9-11. 
independent of foreign assent. "The question of nationality in Turkey, we are told, is a European question, involving all Powers which have treaties with the Sublime Porte. Any law or regulation of this question must be a joint product [oeuvre commun] of the Sublime Porte and representatives of the Powers." ${ }^{41}$ The memorandum argues that the law carefully avoided any retroactive effect or infringement on existing treaties, and denounces this attempt of foreign powers "to interfere in the relations of the Sultan with his subjects." It seems that this assertion was largely respected in the years that followed. In the case of nationality legislation, at least, it appears that the Ottomans achieved some ground in their mid-century efforts to have their sovereignty recognized by the community of nations.

As in many aspects of international law, most of Europe considered the Ottoman laws a curiosity rather than a mainstay. Von Bar and other general treatise writers in international law gave no attention to the 1869 Ottoman nationality law; the interest of these authors in the Ottoman example was limited to the question of extraterritoriality. Valéry states simply that the Ottomans follow the French practice of sanguinis nationality with a strong soli aspect, alongside Belgium, Spain, Greece, Italy, the Netherlands, Sweden, Denmark, Russia, Bulgaria, Persia, and China ${ }^{42}$ Lehr's survey includes Turkey in the community of nationalities. ${ }^{43}$ The serious examinations of Ottoman nationality came in the context of specialized study of Ottoman law. Pierre Arminjon's 1903 Étrangers et protégés dans l'Empire ottoman was the closest study of the topic. ${ }^{44}$ Emmanuel Salem published a four-part study of Turkish nationality in the leading international law journal in $1905-7 .{ }^{45}$ George Young's seven-volume collection of Ottoman law treats nationality under the field of personal status (at odds with its classification as a matter for the Foreign Ministry). ${ }^{46}$

We have seen that the 1869 nationality law was the product of a series of steps toward more positivist determination of membership, beginning with

41. Cogordan, Droit des gens, 549-50. One of the grounds for this claim was an OttomanRussian convention of April 1863 that regulated the implementation of the protégé law of that year.

42. Jules Valéry, Manuel de droit international privé (Paris: Fontemoing et cie, 1914), 144-45.

43. Ernest Lehr, La nationalité dans les principaux Étas du globe (acquisition, perte, recouvrement) (Paris: A. Pedone, 1909), 215-18.

44. For a brief biographical sketch of Arminjon, see Will Hanley, "International Lawyers without Public International Law: The Case of Late Ottoman Egypt," Journal of the History of International Law 18 (2016): 108.

45. Salem, "De la nationalité en Turquie."

46. George Young, Corps de droit ottoman; recueil des codes, lois, règlements, ordonnances et actes les plus importants du droit intérieur, et d'études sur le droit coutumier de l'Empire ottoman, 7 vols. (Oxford: The Clarendon Press, 1905), 2:223-41. 
the Tanzimat and the 1856 reform edict, but depending especially on the 1856 Treaty of Paris and the 1863 protégé regulation. After each step, new and exceptional cases arose revealing the need for further regulation and clarification. After 1869 and through the long Hamidian period, officials in the Foreign Ministry made a good number of piecemeal adjustments to Ottoman nationality policy. ${ }^{47}$ The second constitutional period was a political watershed that offered the occasion for an update, and in 1909 the Foreign Ministry produced a major revision of the forty-year-old Ottoman nationality law. ${ }^{48}$ This revision entailed a line-by-line evaluation of the successes and failures of the 1869 law, and it integrated many nationality policies adopted in the intervening years. The proposed revision, though never implemented, offers the clearest indication of what nationality law meant for those charged with implementing it. The revision was both a response to particular pressures as the empire sought to realign loyalty to the state and staunch internal and external opposition movements and part of the general global movement to standardize statuses in the first decades of the twentieth century.

The typeset revision shares its archival folder with a dozen auxiliary documents, carefully copied on the letterhead of the Nationality Directorate (tâbiiyet müdiriyeti) of the Foreign Ministry, which the drafters of the law considered necessary appendices to support their work. ${ }^{49}$ As Aimee Genell's pioneering article in this issue shows, the history of the legal work of the Ottoman Foreign Ministry is only beginning to emerge, and so it difficult to gauge how well integrated this Directorate, the Legal Bureau, and the Foreign Ministry itself were with the other administrative conduits that governed the Ottoman membership regime. ${ }^{50}$ The draft law was never implemented. Although unimplemented ideas can exert influence on legal practice and on subsequent legislation, such influence has proven difficult to track in this case. ${ }^{51}$ At the

47. In addition to the evidence given elsewhere in this issue, see the rich collection of examples from the 1870s and 1880s published in Kuneralp and Öktem, Chambre des conseillers légistes.

48. BOA, HR.HMŞ.İ̧O, 221/11.

49. In addition to the comments discussed below, the appendices include two further items: item 3 is a firman of 11 Rebiülevvel 1297 (11 Feb. 1880), and item 10 is a copy of the minute (mazbata) of opinion (ray) of the Devlet-i Tanzimat Dairesi number 2607, dated 13 Receb 1310 (31 Jan. 1893), which is a response to request from the Tâbiiyyet Kalemi, about a specific person seeking French nationality in Salonika.

50. The classic account is Carter Vaughn Findley, Bureaucratic Reform in the Ottoman Empire: The Sublime Porte, 1789-1922 (Princeton: Princeton University Press, 1980), 319.

51. On this question, see Tatiana Borisova, "The Digest of Laws of the Russian Empire: The Phenomenon of Autocratic Legality," Law and History Review 30, no. 3 (2012): 903. For a history of Republican Turkish nationality tracing continuity to Ottoman law, see Osman 
very least, the draft law offers the Foreign Ministry's verdict on its own 1869 nationality law.

No end of internal reasons influenced the 1909 revision. Its relatively conservative modernization of existing nationality practices is entirely in step with the conservative aims of the new government, which sought to preserve the empire rather than transform it. And new nationality problems would continue to arise in the months to come: Deringil reports that in 1912-13, the Council of State returned to the question of nationality, declaring that converts to Islam would no longer automatically acquire Ottoman nationality. ${ }^{52}$ But external influences are also clear. The Legal Bureau was a competitor with its counterparts in other states and empires. The Ottomans needed to show their currency and competence on all fronts. The update was not merely a question of keeping up, however. Other states had developed means of dealing with particular kinds of nationality problems, and the Legal Bureau-which followed such developments closely - would have chosen to adopt and import these means where feasible. The foreign ministry was under tremendous pressure to account for Ottoman treatment of its subjects. Major conflicts with the Armenian community and the influx of refugees from Balkan wars each posed nationality problems. "Minority protection" was the euphemism that emerged to describe international interest in these questions, and the Ottomans knew that there was an intense need for response in 1909, in order to forestall further intervention.

\section{The Purview of Nationality}

The meaning of the 1869 nationality law is confirmed by the content of the 1909 revision, which shows what the Ottoman administrators responsible for nationality thought it was. Nationality, in the Ottoman Empire as elsewhere, begins with acquisition - the most basic grounds on which a person can be considered a subject. The opening articles of the 1909 regulation and the 1869 law treats the same three topics - descent, place of birth, and naturalizationbut the 1909 draft is much more extensive and specific, accounting for a broad range of exceptions. First comes jus sanguinis: a male or female, regardless of birthplace, who is the legitimate child of an Ottoman father or the illegitimate child of an Ottoman mother, is an Ottoman national. (The legitimate child of an Ottoman mother and a non-Ottoman father would take the nationality of her or his father). Second comes a quite pervasive definition of subjecthood

Fazû Berki, "Türk Vatandaşlı̆ğ Kanununun Aslî Tabiiyete Müteallik Hükümleri,” Ankara Üniversitesi Hukuk Fakültesi Dergisi 7, no. 1-2 (1950): 146-59.

52. Deringil, Conversion and Apostasy, 187; this issue is also treated in Salem, "De la nationalité en Turquie," 1038-41. 
by residence: any individual, irrespective of birthplace, who is resident in the Ottoman dominions is considered an Ottoman subject - except those who can convince Ottoman officials that they are foreigners. This blanket provision serves to establish a default assumption in cases which otherwise would be open to debate. After these two basic categories, article one details five less frequently occurring forms of basic membership. None of these categories figured in the 1869 law, though some were the subject of directives in the intervening years. The following also counted as Ottoman:

- the foundling children of persons of unknown identity in the Ottoman domains;

- any man or woman who is legally stateless (kaideten vatansiz) and not subject to any foreign government, irrespective of birthplace, who is present on Ottoman territory (osmanlı ülkesinde);

- Muslim Ottoman women who had married Iranian men despite the ban on such marriages, and the sons and daughters of these marriages;

- unregistered persons (nüfus) in localities where the Ottoman census was not carried out; and

- "concealed" (mektûme) persons from localities where the census had been carried out.

Most of these exceptional categories are addressed in greater detail in the articles that follow. The great increase in the kinds of unknowns and exceptions in this article embodies a response to experience. Already, it is clear that this law is the product of the very men in the Legal Bureau of the foreign ministry who had been charged with decades of complex problems resulting from the ambiguities of the 1869 law.

Jus soli is the concern of article two, which specifies that children born in the Ottoman domains to foreign parents may be considered Ottoman subjects, and may hold dual nationality if they apply to the government according to procedures which the draft spells out in considerable detail. Naturalization is the subject of article four, which stated that the foreign born persons could apply for Ottoman naturalization after three years of residence. These applicants must be of the age of majority and free of bankruptcy or criminal conviction, or have been rehabilitated (iade-i itibar eden). Like the previous article, this article describes the application procedure, and goes so far as to state that following investigation of the application, officials have the right either to accept or refuse the request. The injection of procedural details into the statute, as well as the insistence on administrative discretion, shows that the framers of the draft were especially concerned with its application. This concern with spelling out all possibilities is sustained throughout the $1909 \mathrm{draft}$, which also introduces regulation of acquisition through adoption (article three), and the case of children born on ships in Ottoman waters (article five). Executive 
discretion featured in article four of the 1869 law (borrowed from article nine of the French Civil Code), which gave the government the power to admit exceptional individuals to Ottoman nationality in extraordinary circumstances. ${ }^{53}$ The 1909 law much surpassed this general power, carefully encoding in articles six, seven, and eight the government's power to make exceptions to the standard avenues of acquisition. A sign of the times, article nine gave the government special powers to enforce nationality during wartime. In addition to allowing for obscure possibilities and procedures, the regulation greatly expanded administrative prerogative.

As Kern has established, Persia had a major influence on Ottoman nationality; it is not surprising that the 1909 draft looks east as much or more than west or north. In many of its articles, the draft shows a marked resemblance to the first comprehensive Persian nationality law, dated 5 Safer 1312 (8 August 1894). ${ }^{54}$ The Persian law took its first four articles almost verbatim from the Ottoman nationality law of 1869 , adding only, in article three, a provision that naturalizing foreigners must (in addition to being of majority and having resided in Persia for five years) have a clean penal record and be free of military service obligations. Other articles were original, however. Articles five to seven of the Persian law concern the resumption of Persian nationality by expatriates and children of expatriates (they are excused the five-year residence requirement), foreign wives of Persian subjects (they become Persian nationals, but may revert to their original nationality in widowhood or divorce), and foreign wives of foreign subjects (who may only naturalize if their husbands also does so). None of these provisions appear in the 1869 law, but articles six and seven anticipate articles twenty and twenty-one of the 1909 draft law. Similarly, article ten of 1894 (on children's independence from their father's nationality) anticipates article twenty-three of 1909, and article eleven of 1894 (on Persian women following their husband's nationality) resembles article nineteen of 1909.

Most intriguing are articles thirteen and fourteen of the Persian law. Article thirteen mimics article nine of 1869 , stating that "those who appear to be Persian subjects, and yet claim to be subjects of a foreign state, must prove their nationality. ..." But article fourteen turns this idea on its head: "Aliens who have come to Persia, and have concealed their nationality while residing in the Shah's dominions, and have been treated as Persian subjects, or have purchased property, which is the exclusive right of Persian subjects,

53. Arminjon, Étrangers et protégés, 84.

54. Translations of this law appear in British and Foreign State Papers 86 (1893-94), 180-82 and in James Brown Scott, David Jayne Hill, and Gaillard Hunt, "Citizenship of the United States, Expatriation, and Protection Abroad," [59th Cong., 2nd sess., HR Doc. 326] (Washington DC: State Department, 1906), 484-86. 
shall be recognized as Persian subjects, and their claim to foreign protection shall not be admitted." Presumably both articles of the Persian law were intended to address the twin problem of false Ottomans and Ottomans pretending to be Persians. These articles seem to anticipate article one section eight of 1909, which makes "concealed" persons found on the territory Ottoman nationals.

"Concealed" persons were typical of the marginal subjects that were the focus of nationality legislation. The only discussion of the kinds of rights that a citizen might possess concerned the political and property rights of immigrants and refugees. Article fifteen of the 1909 regulation stipulates that the acquisition of Ottoman political rights (hukuk-i siyasiye) by a person entering into Ottoman nationality through naturalization or special government dispensation (articles four to eight) is contingent on ten years' residence in the Ottoman domains from the date of nationality change. ${ }^{55}$ For refugees (muhacirin), however, the period of residence is five years. Extended residence was an important loyalty test. In Ali Pasha's 1869 narrative of the reasons for the promulgation of the law, he complains bitterly that in the years before 1869 , "several states changed their naturalization laws; the condition making residence for a number of years mandatory [before naturalization] was reduced, and even abolished in certain countries." ${ }^{56}$ Forty years later, the Ottomans were careful to test loyalty with time before according political rights. This two-step naturalization shows again that nationality and citizenship rights followed separate tracks. Presumably the loyalty of refugees, who had few other places to go, was more easily (and quickly) assured.

\section{Marriage and Expatriation}

Ottoman administrators demonstrated creative agency during the Hamidian period, but they did so by adapting international norms to local conditions. While most Ottoman nationality legislation duplicates laws found elsewhere, in the case of marriage and expatriation Ottoman lawyers sought to extend control over its subjects beyond the generally-accepted limits of international law. The 1909 draft deals with both of these questions in detail, summarizing four decades of experience and describing a trajectory for the post-Hamidian membership regime.

55. In 1894, a regulation of the Council of State made it possible for foreign converts to Islam who did not fulfill all of the requirements for naturalization to acquire a sort of provisional Ottoman nationality (including the requisite identification documents). Deringil, Conversion and Apostasy, 187.

56. Cogordan, Droit des gens, 549. 
The 1869 law gave slight attention to marriage, stating only that a woman who acquired Ottoman nationality through marriage could return to her original nationality after her husband's death (article seven). The framers of the law did not foresee that marriage would form such a major part of their work in the decades that followed, as the legal bureau was called on again and again to issue opinions on marriage problems. ${ }^{57}$ These problems also required legislation in the intervening years.

Questions of Iranian nationality figure in two appendices attached to the draft law: the well-known marriage regulation dating 5 Şaban 1291 (24 September 1874) and a 5 Receb 1305 (18 March 1888) circular letter to provincial governors specifying treatment for couples who had broken the prohibition on Ottoman/Iranian marriage. ${ }^{58}$ It is clear that the authors of the 1909 law had just these problems in mind as they sought to clarify rules and procedures for the second constitutional period. Generally speaking, the law shows a greater awareness and specificity concerning questions of gender; as the istişare odast nationality opinions of the 1880s and 1890s show, problems arose from the gender vagaries of the 1869 law..$^{59}$ Although nationality differentiation by gender is clear, the 1909 draft is careful to specify its applicability to both male and female subjects in the more commonplace categories of acquisition (whereas the 1869 law mentioned a [generic] "person" [şahis]).

The 1909 draft contains six articles concerning marriage. Article ten states that for the purposes of nationality, the age of majority (twenty-one years of age) is set aside for married Ottoman women and for foreign women married to Ottoman men. Articles nineteen and twenty treat the cases of Ottoman women married to foreign men and Ottoman men married to foreign women, respectively. In both cases, wives follow the nationality of their husbands under most circumstances (though the Ottoman/Iranian marriage ban is specifically referenced in article nineteen). The following three articles further specify possible circumstances: wives changing nationality along with husbands (article twentyone), nationality change after death or divorce (article twenty-two, which again specifically excludes any coverage for Ottoman/Iranian marriages), and the status of children, who do not follow the nationality of their fathers (article twenty-three). ${ }^{60}$ But the draft of 1909 does not encode the marriage ban;

57. Kuneralp and Öktem, Chambre des conseillers légistes.

58. The former document appears in Kern, Imperial Citizen, 159, appendix two. Portions of the latter document appear in Ibid., 103-4.

59. Kuneralp and Öktem, Chambre des conseillers légistes.

60. Articles twenty-two and twenty-three of the 1909 draft seem to correspond to articles seven and eight of the 1869 law. 
instead, it states several times that its provisions do not apply to such forbidden marriages. ${ }^{61}$

Marriage is a major driver of nationality law, but the Persian marriage ban was not about marriage per se but a part of a broader effort to retain population. ${ }^{62}$ This was also the ambit of the second distinctive aspect of Ottoman nationality law: its attempt to restrict naturalization under foreign nationality by Ottoman subjects. The core feature of the 1869 law was the stipulation that the Ottoman state was not bound to recognize any other state's naturalization of an Ottoman subject. This feature, which had been the subject of considerable diplomatic controversy over the intervening decades, was reiterated and further specified in articles eleven to sixteen of the 1909 draft. $^{63}$ Article five of the 1869 law tersely stated that foreign naturalization was permitted, but required an imperial irade, and reserved for the Ottoman state the right to disregard any unauthorized naturalization.

George Young reported in 1905 that it had become almost impossible to procure this irade. To do so, the consular authorities of the state to which the petitioner had naturalized had to send a copy of the certificate to the Ottoman Ministry of Foreign Affairs. He also had to submit a declaration that he would leave the empire as soon as the irade was granted. The file was then sent to local authorities at the petitioner's place of residence to ensure that there were no legal, tax, or other issues outstanding. The Porte was then able to request an irade, but would only do so if the petitioner had influence; in practice, it happened very rarely ${ }^{64}$ In 1906 , the Nationality Bureau published a detailed price list for all of its procedures. ${ }^{65}$ Presumably, the standardization of forms and procedures in 1909 was an effort to streamline a process developed in the intervening years. ${ }^{66}$

Most of these procedures were restrictive. Ottoman subjects needed permission to leave the dominions at all (article eleven), and of course could only denaturalize with authorization (article twelve). Article thirteen specified the formalities required for such an authorization. Article fourteen detailed the

61. The 1894 Persian nationality law does not reciprocate the Ottoman prohibition of marriage with Persian subjects.

62. On global efforts to retain population in this period, see Adam McKeown, Melancholy Order: Asian Migration and the Globalization of Borders (New York: Columbia University Press, 2008).

63. On the controversy, see Qafisheh, International Law Foundations, 33.

64. Young, Corps de droit ottoman, 2:227.

65. Ibid., 7:339.

66. Articles eight and nine of the 1894 Persian nationality law concern expatriation. Article eight states that expatriates must be free of criminal sentences, judicial proceedings, military service obligations, and liabilities in Persia, while article nine reproduces the sanctions for unauthorized expatriation in article six of the 1869 law. 
registration procedures for naturalized Ottomans. Article sixteen explained the consequences of leaving Ottoman residence and Ottoman nationality. Among these consequences was banishment; article eighteen states that denaturalized Ottomans could not return to the empire. This confirmed and extended practice already present in an irade of 9 October 1896 concerning Armenians naturalized in the United States especially, which stated that passports delivered to these persons showed that they "will not be allowed to set foot again on Ottoman territory." ${ }^{\prime 67}$ Article twenty-five specified punishment for nationality fraud. Five model forms to accomplish naturalization and nationality formalities are included in the handwritten appendices to the draft. These include a shorter and longer identity form model for those returning to Ottoman nationality (items six and seven), as well as a model authorization letter (ruhsat-name) (item eight). Item nine is an oath form for those returning to Ottoman nationality, and item eleven is another medium sized identification form model. ${ }^{68}$

Territorial access and property rights offered teeth to denaturalization controls. After the 1869 law, a series of regulations attacked the property rights of denaturalized Ottomans. The 1909 draft enshrines these rules in article seventeen. Since the 1860 s, Ottoman subjects who changed nationalities had been subject to considerable disabilities within the empire. After 1867, they were prohibited from owning real property on Ottoman territory. ${ }^{69}$ In 1873 , foreign husbands and children were prohibited from inheriting from Ottoman wives and mothers. ${ }^{70}$ Appendix twelve in the archival file is a four-article law dated 25 Rebiülahir 1300 (5 March 1883) on the property rights of foreigners (ecanibin hakk-ı istimlâk-i kanunu). This law prohibited Ottomans who took a foreign nationality without permission from inheriting real property. ${ }^{71}$ Miri and vakuf property would be treated as if there were no heir, while mülk land would

67. John Bassett Moore, A Digest of International Law, 8 vols. (Washington DC: Government Printing Office, 1906), 3:706, cited in Qafisheh, International Law Foundations, 33.

68. On the late Hamidian nationality document regime, see Osmanağaoğlu, Osmanlı tâbiiyyeti, 282-89.

69. This rule referenced in American dispatches of 1897 and 1898 in Moore, Digest, 3:696. Also cited as "Law concerning the Disposition of Foreign Subjects of Property, 6 Safar 1284" ('Arif Ramadan and Yusuf Ibrahim Sadir, eds., Majmu'at al-qawanin: tahtawi 'ala jami' al-qawanin al-ma 'mil bi-mawjibiha fi jami' al-bilad al-'Arabiyah al-munsalikhah 'an al-hukümah al- 'uthmaniyah, 7 vols. (Beirut: al-Matba'ah al-'Ilmiyah, 1925), 3:139) in Qafisheh, International Law Foundations, 32.

70. Cited as "Instructions Concerning Inheritance of Foreigner's Wives Who are Nationals of the State" (Ramadan and Sadir, Majmu 'at al-qawanin, 3:141) in Qafisheh, International Law Foundations, 32.

71. This regulation is discussed in Belkıs Konan, "Osmanlı Devletinde Yabanc1ların Kapitülasyonlar Kapsamında Hukuki Durumu” (PhD diss., Ankara University, 2006), 106-9. 
be apportioned amongst heirs who were Ottoman nationals. ${ }^{72}$ Property rights had been reformulated in such a way that nationals and non-nationals felt a difference. Ottoman Zionists realized that participation in the political project required Ottoman nationality, and they urged Jews resident in the Ottoman domains to take out nationality papers. ${ }^{73}$

What was the source of this draconian approach to foreign naturalization? Qafisheh suggests that the Ottoman prohibition of nationality change was a holdover from Islamic notions of membership, which forbade conversion from Islam. ${ }^{74}$ Parolin supports this view. ${ }^{75}$ Kern's analysis of marriage regulations and Deringil's work on conversion suggests a sort of religious mercantilism, an effort to stockpile subjects in order to protect the prestige of the sultancaliph. ${ }^{76}$ As the domestic and foreign legal context of the 1909 draft presented in this paper shows, however, the protectionism was in large measure a reaction to lingering fears of Capitulations abuses. The 1863 protégé regulation and the 1869 nationality laws were not intended to form a citizenry. They aimed to shore up the government's sovereignty over its resident population in the face of extraterritorial claims. It was the responsibility of the Foreign Ministry, not the Interior Ministry, to ensure that a bounded population was established. The greatest threat to Ottoman population was not conversion or emigration-it was subversion from within, through foreign privilege. This is the longstanding fear that the 1909 draft, entirely in line with the anti-Capitulations policy priorities of the Committee of Union and Progress, sought to assuage.

\section{Conclusion}

Ottoman nationality aimed to draw a fragmenting group of subjects closer to the centralizing Tanzimat and Hamidian states. It did so with legal tools that seem ill-suited to the rough and ready nature of both Hamidian control and the opposition to it. At the same time, legal status offered a front of comparative advantage to the Ottoman state, which was - despite everything - the most competent bureaucracy and authority in the eastern Mediterranean. The 1909 revision was consonant with other Ottoman bureaucratic developments of the period. What is curious is that the regimes that succeeded Abdülhamid, which strengthened many of his rationalizing procedures, did not see fit to revise

72. Young cites an Interior Ministry circular to the same effect dated several months earlier on 14 Mart 1299 (26 May 1882). Young, Corps de droit ottoman, 4:228.

73. Cohen, Becoming Ottomans, 104.

74. Qafisheh, International Law Foundations, 27.

75. Parolin, Citizenship.

76. Kern, Imperial Citizen; Deringil, Conversion and Apostasy. 
Ottoman nationality, even as they pressed their subject populations harder and harder to conform to the state's will.

In the global context, the 1909 revision is an example of modular, standardized legal vision. It aimed to enact the Ottoman claim to commensurate status as a member of the community of nations better than the 1869 law, just as the 1869 law was a more modular, standardized approach to the problems that the 1863 protégé regulation sought to address. In both cases, the lawyers adopted international language and sidestepped local idiosyncrasies in favor of flatter, more general, and much more specific provisions. The draft revision of 1909 captures their aim to use nationality to transform a disparate Ottoman population into a homogeneous unit. The literature on the late Ottoman Empire reveals that the empire's other administrative and bureaucratic wings shared the same objective but tackled it using different tools. The workers at the Foreign Ministry's Legal Bureau clearly saw themselves as part of a global community of international lawyers. ${ }^{77}$ In the prologue to the 1909 revision, they insisted on only one Ottoman particularity: "Every problem of nationality has greater importance and delicacy for the Ottoman Empire than for any other place."

WILL HANLEY is an Assistant Professor in the Department of History at Florida State University, Tallahassee, FL. (whanley@fsu.edu)

77. This community is described in Martti Koskenniemi, The Gentle Civilizer of Nations: The Rise and Fall of International Law, 1870-1960 (Cambridge, UK: Cambridge University Press, 2002); Arnulf Becker Lorca, Mestizo International Law: A Global Intellectual History, 1850-1950 (Cambridge, UK: Cambridge University Press, 2015). 